\title{
The Catabolism of 4-Hydroxyacetophenone by an Alcaligenes sp.
}

\author{
By DAVID J. HOPPER, ${ }^{1 *}$ H. GWYN JONES, ${ }^{1}$ ELMORSI A. ELMORSI ${ }^{1}$ AND \\ MURIEL E. RHODES-ROBERTS ${ }^{2}$ \\ Departments of ${ }^{1}$ Biochemistry and Agricultural Biochemistry and ${ }^{2}$ Botany and Microbiology, \\ University College of Wales, Aberystwyth, Dyfed SY23 3DD, UK
}

(Received 20 December 1984; revised 28 February 1985)

\begin{abstract}
A bacterium capable of growth on 4-hydroxyacetophenone was isolated from soil and identified as an Alcaligenes sp. Intact cells rapidly oxidized (4-hydroxybenzoyl)methanol, 4-hydroxybenzoate and protocatechuate as well as the growth substrate, and also converted the substrate analogue (4-methoxybenzoyl)methanol to 4-methoxybenzoic acid. When provided with NADH, cell-free extracts oxidized 4-hydroxyacetophenone to 4-hydroxybenzoate and formate, the same products as were formed from (4-hydroxybenzoyl)methanol without NADH. The oxidation of 4-hydroxybenzoate by cell-free extracts required NADPH and the product from both this and protocatechuate oxidation was 3-oxoadipate. A pathway for the catabolism of 4hydroxyacetophenone, by hydroxylation to (4-hydroxybenzoyl)methanol followed by oxidative cleavage to 4-hydroxybenzoate and formate and hydroxylation of the 4-hydroxybenzoate to protocatechuate, is proposed. Oxidation of protocatechuate was by the ortho pathway. The key enzymes in the proposed pathway were induced by growth on 4-hydroxyacetophenone.
\end{abstract}

\section{INTRODUCTION}

The initial attack in the bacterial catabolism of aromatic compounds often involves modification and, in some cases, removal of side-chains in preparation for ring-fission. Thus, in the metabolism of acetophenone by species of Arthrobacter and Nocardia the ketonic side-chain is removed and the compound converted into phenol (Cripps, 1975; Cripps et al., 1978). The phenol is then hydroxylated to give catechol, the ring-fission substrate. Removal of the sidechain is achieved by the insertion of an oxygen atom between the keto group and the aromatic ring, catalysed by a mono-oxygenase, to form the ester, phenyl acetate, which is then hydrolysed by an esterase. Several other examples of this procedure for dealing with ketonic compounds are known, including the bacterial conversion of cyclohexanone into $\varepsilon$-hexanolactone (Norris \& Trudgill, 1971), tridecanone into undecylacetate (Forney \& Markovetz, 1969) and the fungal conversion of progesterone into testosterone acetate (Rahim \& Sih, 1966). In each case the ester or lactone produced is then cleaved hydrolytically. The generalized scheme for this is:

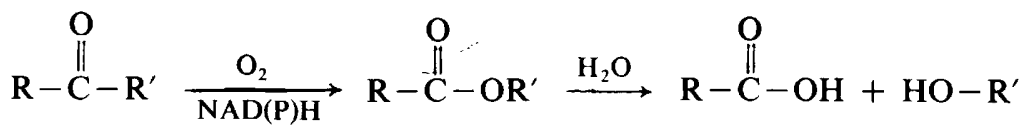

A different method is used by Aspergillus niger to metabolize phloretin $\left(2^{\prime}, 4,4^{\prime}, 6^{\prime}\right.$ tetrahydroxydihydrochalcone) which, like acetophenone, contains a keto group adjacent to an aromatic ring. In this case, the side-chain is removed hydrolytically with no involvement of a mono-oxygenase or ester formation (Minamikawa et al., 1970). The hydrolase is active with a number of chalcones and substituted acetophenones but requires hydroxyl groups in both the 2and 4-positions in the ring. Thus 4-hydroxyacetophenone is not a substrate.

4-Hydroxyacetophenone can be formed by bacterial oxidation of 4-ethylphenol due to the action of the enzyme $p$-cresol methylhydroxylase (McIntire et al., 1984). Preliminary studies of 
its metabolism by a Nocardia sp. indicated that neither of the previously described routes for acetophenones was utilized (Whateley, 1978), and this possibility of a new mechanism for dealing with a ketonic side-chain led us to a fuller investigation of the catabolism of 4hydroxyacetophenone. We have already reported an unusual reaction, occurring in a bacterium isolated on 4-hydroxyacetophenone, in which (4-hydroxybenzoyl)methanol is split in an oxygenrequiring reaction to give formate and 4-hydroxybenzoate (Hopper \& Elmorsi, 1984). Here we identify the bacterium as an Alcaligenes sp., and present evidence for a pathway of 4hydroxyacetophenone catabolism that includes this unusual reaction as one of the steps.

\section{METHODS}

Identification of organism. The bacterium, strain PFA, is a Gram-negative, non-capsulated coccobacillary rod $0.7-1.5 \times 0.7 \mu \mathrm{m}$, with one to six peritrichate flagella. Its properties in a range of standard cytological and biochemical tests were in agreement with the genus description of Alcaligenes (Holding \& Shewan, 1974), with the exception that it was resistant to sulphamethoxazole/trimethoprim and slightly sensitive to streptomycin. It would be necessary to check for hydrogen autotrophy to eliminate the possibility that the organism was A. eutrophus; otherwise strain PFA closely resembles Alcaligenes faecalis.

Growth of organism. The growth medium contained (per litre): $\mathrm{Na}_{2} \mathrm{HPO}_{4}, 4.33 \mathrm{~g} ; \mathrm{KH}_{2} \mathrm{PO}_{4}, 2.65 \mathrm{~g} ; \mathrm{NH}_{4} \mathrm{Cl}$, $2.0 \mathrm{~g}$; nitrilotriacetic acid, $0.1 \mathrm{~g}$; 4-hydroxyacetophenone, $0.5 \mathrm{~g}$ or sodium succinate, $1.0 \mathrm{~g} ; 4 \mathrm{ml}$ salts solution (Rosenberger \& Elsden, 1960). Bacteria were grown in $100 \mathrm{ml}$ medium in $250 \mathrm{ml}$ Erlenmeyer flasks at $30^{\circ} \mathrm{C}$ on an orbital shaker (Gallenkamp; 150 r.p.m.), and then inoculated into 1 litre of medium in a 2 litre Erlenmeyer flask and incubated in the same way. These cultures were used for Warburg experiments and to inoculate 10 litres of medium in a Microferm MF-114 fermenter (New Brunswick Scientific Co.). The vessel was maintained at $30^{\circ} \mathrm{C}$, aerated at a rate of 4 litres $\mathrm{min}^{-1}$ and stirred at 150 r.p.m. Growth was followed by measuring $\mathrm{OD}_{540}$. The 1 litre cultures were harvested by centrifuging at $5000 \mathrm{~g}$ for $20 \mathrm{~min}$. The fermenter cultures were harvested using an Alpha Laval LAB 102B continuous flow centrifuge (Alpha Laval, Brentford); organisms were washed with $50 \mathrm{mM}$-phosphate buffer, $\mathrm{pH} 7.0$ and, if not used immediately, stored at $-20^{\circ} \mathrm{C}$.

Preparation of bacterial extracts. Frozen suspensions were thawed in 1 vol. $42-\mathrm{mM}$ phosphate buffer, $\mathrm{pH} 7 \cdot 0$, and the bacteria were disrupted by passage through a precooled French pressure cell with a pressure difference of 138 $\mathrm{MPa}$ at the orifice. Unbroken bacteria and large particulate material were removed by centrifuging at $23000 \mathrm{~g}$ for $20 \mathrm{~min}$ at $2{ }^{\circ} \mathrm{C}$. The supernatant solution was retained and is referred to as the crude extract. $\left(\mathrm{NH}_{4}\right)_{2} \mathrm{SO}_{4}$-treated extract was prepared by precipitating the protein in the crude extract by the slow addition of $\left(\mathrm{NH}_{4}\right) \mathrm{SO}_{4}$ $\left(0.476 \mathrm{~g} \mathrm{ml}^{-1}\right)$ at $0{ }^{\circ} \mathrm{C}$, followed by centrifuging at $25000 \mathrm{~g}$ for $10 \mathrm{~min}$. The pellet was redissolved in $50 \mathrm{mM}-$ phosphate buffer, $\mathrm{pH} 7.0$, and the solution dialysed against 100 vols buffer for $4 \mathrm{~h}$ at $2{ }^{\circ} \mathrm{C}$.

Chromatography. TLC was done using precoated silica-gel GHLF plates (Analtech, Newark, NJ, USA) with solvents A [toluene/dioxan/acetic acid $\left(90: 25: 4\right.$, by vol.)] and B [light petroleum, (b.p. 60 to $80^{\circ} \mathrm{C}$ )/ethyl formate/propionic acid $(70: 30: 15 \cdot 4$, by vol.) (Ronkainen, 1963)]. Aromatic compounds were located by viewing under UV light for materials that quenched the fluorescence of the indicator in the plates. Acids were located by spraying with $0.1 \%$ bromocresol green and phenolics by spraying with diazotized $p$-nitroaniline.

Spectra. UV absorption spectra were recorded with a Unicam SP8-150 spectrophotometer. For IR spectra, samples were mulled in Nujol and their spectra recorded with a Perkin-Elmer Infracord spectrophotometer.

Warburg manometry. A conventional Warburg apparatus was used for $\mathrm{O}_{2}$ uptake measurements. The details for experiments with intact cells are given in the legend to Fig. 2. For experiments with cell-free extracts, flasks were shaken at $30^{\circ} \mathrm{C}$ and contained about $20 \mathrm{mg}$ extract protein and $3 \mu \mathrm{mol}$ substrate in $1.8 \mathrm{ml} 42 \mathrm{~mm}$-phosphate buffer, $\mathrm{pH} 7.0$, with $0.2 \mathrm{ml} 20 \%(\mathrm{w} / \mathrm{v}) \mathrm{KOH}$ in the centre well. When an NADH-generating system was required, $1 \mu \mathrm{mol} \mathrm{NAD}+, 20 \mu \mathrm{mol}$ ethanol and $0.1 \mathrm{mg}$ alcohol dehydrogenase $(35.2$ units) were included in the reaction mixture. For an NADPH-generating system, $1 \mu \mathrm{mol} \mathrm{NADP+}, 10 \mu \mathrm{mol}$ glucose 6-phosphate and 3 units of glucose-6-phosphate dehydrogenase were included in the reaction mixture.

Assays. Esterase activity was monitored with a pH-stat as described by Norris \& Trudgill (1971), but with methyl 4-hydroxybenzoate as substrate instead of $\varepsilon$-hexanolacetone and with $3 \mathrm{mg}$ crude extract protein.

(4-Hydroxybenzoyl)methanol cleavage enzyme was assayed as described by Hopper \& Elmorsi (1984).

4-Hydroxybenzoate hydroxylase was assayed spectrophotometrically by following the decrease in $A_{340}$, at $30^{\circ} \mathrm{C}$ in a $1 \mathrm{~cm}$ pathlength semimicro cuvette, of $1 \mathrm{ml}$ of a reaction mixture containing $50 \mathrm{mM}$-phosphate buffer, $\mathrm{pH} 7 \cdot 0$, $1.5 \mu \mathrm{mol} 4$-hydroxybenzoic acid, $0.3 \mu \mathrm{mol}$ NADPH and cell-free extract. Activity was also demonstrated by following $\mathrm{O}_{2}$ consumption, with a Clark-type oxygen electrode in a stirred reaction vessel at $30^{\circ} \mathrm{C}$, by a $3 \mathrm{ml}$

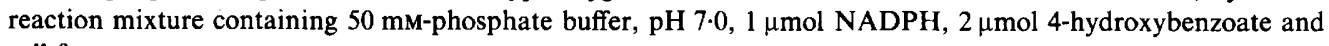
cell-free extract.

Protocatechuate oxygenase was assayed by following $\mathrm{O}_{2}$ consumption with an oxygen electrode at $30^{\circ} \mathrm{C}$. The

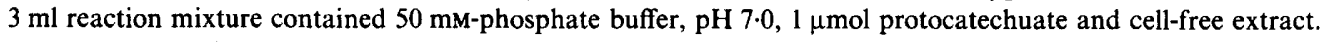


(4-Hydroxybenzoyl)formate decarboxylase was assayed by measuring $\mathrm{CO}_{2}$ production in the Warburg apparatus as described by Kennedy \& Fewson (1968).

Protein was assayed by the biuret method with bovine serum albumin as the standard.

The presence of 3-oxoadipate in reaction mixtures was demonstrated by the Rothera reaction (Rothera, 1908).

Buffers. Phosphate buffers were prepared by titrating a solution of $\mathrm{KH}_{2} \mathrm{PO}_{4}$ to the required pH with $0.5 \mathrm{M}$ $\mathrm{NaOH}$ and diluting to the required concentration.

Preparation of 2,4-dinitrophenylhydrazones. 3-Oxoadipate in reaction mixtures was identified by chromatography of the 2,4-dinitrophenylhydrazone. This was prepared by incubation of the deproteinized mixture with $0 \cdot 1 \%$ 2,4-dinitrophenylhydrazine in $2 \mathrm{M}-\mathrm{HCl}$ for $30 \mathrm{~min}$ at $30^{\circ} \mathrm{C}$. This was extracted into ethyl acetate and then reextracted into $10 \%(\mathrm{w} / \mathrm{v}) \mathrm{Na}_{2} \mathrm{CO}_{3}$. This solution was washed with ethyl acetate, acidified and the 2,4dinitrophenylhydrazone extracted into ethyl acetate, which was then dried over anhydrous $\mathrm{Na}_{2} \mathrm{SO}_{4}$ and evaporated to dryness.

Chemicals. (4-Hydroxybenzoyl)methanol was prepared by the procedure of Robertson \& Robinson (1928). (4Hydroxyphenyl)glyoxal was prepared by the $\mathrm{SeO}_{2}$ oxidation of 4-hydroxyacetophenone by following the procedure described by Vogel (1956) for phenylglyoxal preparation from acetophenone. (4-Hydroxybenzoyl)formate was prepared by the cold-permanganate oxidation of 4-hydroxyacetophenone. 4-Hydroxyacetophenone was from Aldrich. 4-Hydroxybenzoic acid and methyl 4-hydroxybenzoate were from BDH.

\section{RESULTS AND DISCUSSION}

\section{Isolation of the bacterium}

The Alcaligenes sp., strain PFA, was isolated from soil by elective culture in liquid medium containing $3.7 \mathrm{mM}-4$-hydroxyacetophenone as the sole carbon source.

The isolate exhibited marked colonial pleomorphism under standardized conditions, despite repeated cloning of single colonies. After $3 \mathrm{~d}$ incubation at $25^{\circ} \mathrm{C}$ plates of glucose nutrient agar or King's B agar streaked with single-colony clones contained rough, smooth and mucoid cream or pale yellow colonies ranging from 1 to $9 \mathrm{~mm}$ in diameter, and continued incubation often resulted in irregular clearing of mucoid colonies, and the development of distinct 'petite' microcolonies within the larger colonies (see Fig. 1). However, all the colony variants behaved similarly both qualitatively and quantitatively in a wide range of cytological and biochemical tests.

\section{Oxidations by intact cells}

The oxidation of various compounds by intact bacteria grown on 4-hydroxyacetophenone is shown in Fig. 2. None of these compounds was oxidized immediately by succinate-grown bacteria.

If 4-hydroxyacetophenone was being metabolized in a manner similar to that described for acetophenone (Cripps, 1975), involving an ester-forming mono-oxygenase followed by an esterase, then either hydroquinone or 4-hydroxybenzoate would be formed, depending on which side of the keto group the oxygen was inserted. The lack of $\mathrm{O}_{2}$ uptake with hydroquinone as substrate, coupled with the rapid oxidation of 4-hydroxybenzoate (Fig. 2) suggested that if such a mechanism was operating it was via the second alternative, with the intermediate formation of the ester, methyl 4-hydroxybenzoate. However, the very low rate of oxidation of this latter compound, together with the rapid rate for (4-hydroxybenzoyl)methanol suggested a different route to 4-hydroxybenzoate with initial attack on the methyl group, possibly with its oxidation to carboxyl to give (4-hydroxybenzoyl)formate. This compound is a known intermediate in the catabolic pathway for 4-hydroxymandelic acid in which it undergoes decarboxylation to 4hydroxybenzaldehyde followed by oxidation to 4-hydroxybenzoic acid (Gunter, 1953; Kennedy $\&$ Fewson, 1968). However, it should be noted that (4-hydroxybenzoyl)formate was not oxidized by intact bacteria, and the intermediate aldehyde, (4-hydroxyphenyl)glyoxal, was oxidized relatively slowly and to a limited extent, casting some doubt on this as a possible route to 4hydroxybenzoate.

Of the common ring-fission substrates tested, neither catechol nor gentisate was oxidized immediately whereas there was rapid $\mathrm{O}_{2}$ uptake with protocatechuate (Fig. 2). This is consistent with the possibility that 4-hydroxybenzoate is an intermediate since its catabolism in bacteria often proceeds by hydroxylation to protocatechuate as the ring-fission substrate. 


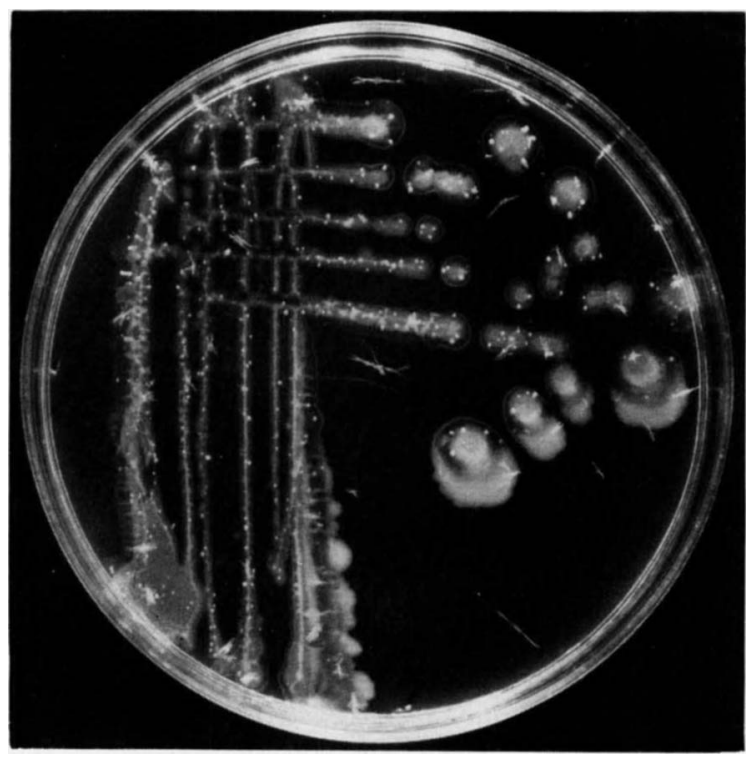

Fig. 1. Isolate of Alcaligenes strain PFA, clone no. 1, grown on King's B agar ( $85 \mathrm{~mm}$ plate) for $10 \mathrm{~d}$ at $25^{\circ} \mathrm{C}$, showing partially cleared mucoid colonies and 'petite' microcolonies growing within the larger colonies.

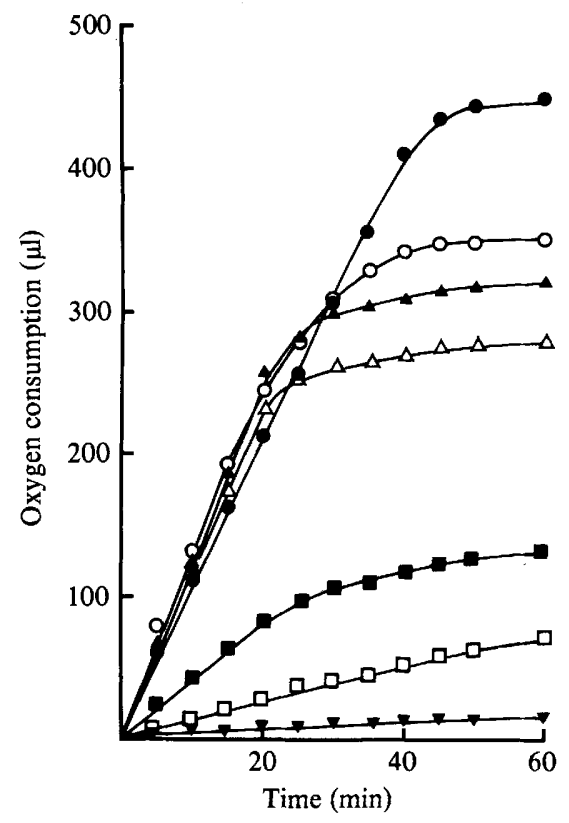

Fig. 2. Oxidation of various compounds by Alcaligenes strain PFA grown on 4-hydroxyacetophenone. Warburg flasks contained $6.4 \mathrm{mg}$ dry weight bacteria in $1.5 \mathrm{ml} 50 \mathrm{mM}$-phosphate buffer, $\mathrm{pH} 7 \cdot 0,0.3 \mathrm{ml}$ $10 \mathrm{mM}$-substrate tipped from the sidearm and $0.2 \mathrm{ml} 20 \%(\mathrm{w} / \mathrm{v}) \mathrm{KOH}$ in the centre well. Oxygen uptake was measured at $30^{\circ} \mathrm{C}$. The uptake in a flask lacking substrate $\left(73 \mu \mathrm{O}_{2} \mathrm{~h}^{-1}\right)$ has been subtracted. The substrates were: 0 , 4-hydroxyacetophenone; $O$, (4-hydroxybenzoyl)methanol; $\Delta$, 4-hydroxybenzoic acid: $\triangle$, protocatechuic acid; $\mathbf{\square}$, (4-hydroxyphenyl)glyoxal; $\square$, methyl 4-hydroxybenzoate; $\nabla$, (4hydroxybenzoyl)formic acid, hydroquinone. 


\section{Oxidation of (4-methoxybenzoyl)methanol}

The oxidation studies with intact cells suggested 4-hydroxybenzoate as an intermediate in 4hydroxyacetophenone metabolism and, with the rapid oxidation of (4-hydroxybenzoyl)methanol, possibly hydroxylation of the methyl group as the first step.

Confirmation that the hydroxylated methyl group can be removed to yield an acid came from identification of the product of partial oxidation of the substrate analogue (4-methoxybenzoyl)methanol as anisic (4-methoxybenzoic) acid. A $250 \mathrm{ml}$ Erlenmeyer flask containing, in $100 \mathrm{ml}$ $50 \mathrm{~mm}$-phosphate buffer, $\mathrm{pH} 7 \cdot 0,85 \mathrm{mg}$ dry weight of 4-hydroxyacetophenone-grown bacteria and $30 \mathrm{mg}$ (4-methoxybenzoyl)methanol, was incubated with shaking at $30^{\circ} \mathrm{C}$ for $3 \mathrm{~h}$. The bacteria were then removed by centrifuging at $12000 \mathrm{~g}$ for $10 \mathrm{~min}$; the supernatant solution was acidified with $2 \mathrm{M}-\mathrm{HCl}$ to $\mathrm{pH} \mathrm{l}$, and extracted twice with an equal volume of diethyl ether. The ether was dried over anhydrous $\mathrm{Na}_{2} \mathrm{SO}_{4}$ and then evaporated to dryness. Examination of the product by TLC with solvent $\mathrm{A}$ showed two major spots, one corresponding to the starting material $\left(R_{F} 0.58\right)$, and the other an acid compound corresponding to anisic acid $\left(R_{F} 0.66\right)$. The neutral starting substrate was removed by dissolving the mixture in $5 \mathrm{ml} 0.2 \mathrm{M}$-phosphate buffer, $\mathrm{pH} 7 \cdot 0$, and extracting twice with diethyl ether. The aqueous fraction was then acidified with $2 \mathrm{M}-\mathrm{HCl}$ and re-extracted with diethyl ether, which was then dried over anhydrous $\mathrm{Na}_{2} \mathrm{SO}_{4}$ and evaporated to dryness. The product gave the same UV and IR spectra as authentic anisic acid.

\section{Activities in extracts}

There was no oxidation of 4-hydroxyacetophenone by crude extracts in a Warburg apparatus unless an NADH-generating system was included in the reaction mixture. Under these conditions the substrate was oxidized rapidly, but with a much lower $\mathrm{O}_{2}$ uptake than would be required for complete oxidation. The stoichiometry of $\mathrm{O}_{2}$ uptake was variable, but attempts to decrease endogenous rates by various treatments of the extract led to loss of activity. However, usually about $2 \mu \mathrm{mol} \mathrm{O}_{2}$ were taken up per $\mu \mathrm{mol}$ of substrate, although in some experiments this represented a marked decrease in the uptake rate rather than a complete cessation of oxidation. The product of the partial oxidation of $3 \mu \mathrm{mol} 4$-hydroxyacetophenone by crude extract in a Warburg flask was extracted with diethyl ether after acidification with an equal volume of $25 \%$ $(w / v)$ metaphosphoric acid and removal of the precipitated protein by centrifuging. The ether was dried over anhydrous $\mathrm{Na}_{2} \mathrm{SO}_{4}$ and evaporated to dryness. When examined by TLC with solvents $\mathrm{A}$ and $\mathrm{B}$ the product showed up as an acid after spraying with bromocresol green, reacted as a phenol by giving a colour with diazotized $p$-nitroaniline, and had the same $R_{F}$ values as authentic 4-hydroxybenzoic acid. The UV spectrum in $50 \mathrm{~mm}$-phosphate buffer, $\mathrm{pH} 7 \cdot 0$, was also identical to that for 4-hydroxybenzoate. Thus cell-free extracts were able to convert 4hydroxyacetophenone to 4-hydroxybenzoate. The 4-hydroxybenzoate accumulated because, as shown later, the enzyme for its hydroxylation to protocatechuate is NADPH-dependent and has no activity with NADH.

The NADH requirement for 4-hydroxyacetophenone oxidation and the production of 4hydroxybenzoate were still consistent with the ester-forming route, but the doubts about this pathway, arising from the experiments with intact cells, were confirmed when no esterase activity towards methyl 4-hydroxybenzoate could be detected in cell-free extracts with a pH-stat. In contrast, a known esterase, the $\varepsilon$-hexanolactone hydrolase in extracts of Nocardia globerula CLI (Norris \& Trudgill, 1971), was clearly demonstrated under the same conditions when used to check the assay system. Similarly the possible route involving the complete oxidation of the methyl group to carboxyl was rendered unlikely when no (4-hydroxybenzoyl)formate decarboxylase could be detected in cell-free extracts and no (4-hydroxyphenyl)glyoxal dehydrogenase was found. The first putative intermediate of attack on the methyl group, (4hydroxybenzoyl)methanol, was, however, readily oxidized by extracts with no requirement for added cofactors, and we have shown in a separate report that this involves an $\mathrm{O}_{2}$-requiring reaction in which this substrate is converted directly to 4-hydroxybenzoate and formate without the intermediate formation of (4-hydroxyphenyl)glyoxal, (4-hydroxybenzoyl)formate or 4hydroxybenzaldehyde (Hopper \& Elmorsi, 1984). 


\section{Table 1. Specific activities of enzymes in cell-free extracts}

Crude extracts from 4-hydroxyacetophenone-grown $\left(11.8 \mathrm{mg}\right.$ protein $\left.\mathrm{ml}^{-1}\right)$ and succinate-grown $\left(18.1 \mathrm{mg}\right.$ protein $\left.\mathrm{ml}^{-1}\right)$ bacteria were assayed as described in Methods. The spectrophotometric assay for 4-hydroxybenzoate hydroxylase was used. Specific activities are expressed as $\mu$ mol substrate transformed $\min ^{-1}$ (mg protein) ${ }^{-1}$.

\begin{tabular}{lcc} 
Enzyme & \multicolumn{2}{c}{ S-Hydroxyacetophenone- } \\
grown bacteria & $\begin{array}{c}\text { Succinate-grown } \\
\text { bacteria }\end{array}$ \\
$\begin{array}{c}\text { (4-Hydroxybenzoyl)methanol } \\
\text { cleaving enzyme }\end{array}$ & 0.081 & $<0.0003$ \\
$\begin{array}{l}\text { 4-Hydroxybenzoate hydroxylase } \\
\text { Protocatechuate oxygenase }\end{array}$ & 0.108 & $<0.0001$ \\
& 0.051 & 0.0004
\end{tabular}

If this latter reaction operates in the degradation of 4-hydroxyacetophenone then formate as well as 4-hydroxybenzoate should be a product of oxidation of this compound by cell-free extracts and this was confirmed in the following experiment. A reaction mixture $(18 \mathrm{ml})$ containing $42 \mathrm{~mm}$-phosphate buffer, $\mathrm{pH} 7.0,79 \mathrm{mg}$ of protein from the supernatant solution after centrifuging crude extract at $190000 \mathrm{~g}_{\mathrm{av}}$ for $1 \mathrm{~h}, 200 \mu \mathrm{mol}$ ethanol, $10 \mathrm{mg} \mathrm{NAD}{ }^{+}, 1 \mathrm{mg}$ alcohol dehydrogenase and $30 \mu \mathrm{mol}$ 4-hydroxyacetophenone was incubated in a $100 \mathrm{ml}$ Erlenmeyer flask with shaking at $30^{\circ} \mathrm{C}$ for $90 \mathrm{~min}$. The reaction products were extracted and identified as 4-hydroxybenzoate and formate by the procedures described by Hopper $\&$ Elmorsi (1984). Thus the conversion of 4-hydroxyacetophenone to 4-hydroxybenzoate does appear to involve the direct cleavage of (4-hydroxybenzoyl)methanol, a conclusion strengthened by the finding that the enzyme responsible was induced by growth on 4-hydroxyacetophenone (Table 1).

Since this cleavage reaction will proceed without added cofactors, the NADH is probably required for a mono-oxygenase catalysing the first step in 4-hydroxyacetophenone oxidation, the hydroxylation of the methyl group. Attempts to separate the enzyme involved in order to demonstrate the hydroxylation in isolation led to loss of its activity but it is clearly inferred from the results described.

\section{Oxidation of 4-hydroxybenzoate and protocatechuate by cell-free extracts}

4-Hydroxybenzoate hydroxylase activity was detected in cell-free extracts of bacteria grown on 4-hydroxyacetophenone (Table 1). This was dependent on the addition of NADPH, with no oxidation occurring when this was replaced by NADH. The enzyme could be assayed either spectrophotometrically by following the oxidation of NADPH, or by using an $\mathrm{O}_{2}$ electrode to measure $\mathrm{O}_{2}$ uptake. Protocatechuate oxygenase was also present at high activity in these extracts (Table 1). When these two substrates were oxidized by an ammonium sulphate-treated extract in a Warburg apparatus, the $\mathrm{O}_{2}$ uptake approached $2 \mu \mathrm{mol}(\mu \mathrm{mol} \text { 4-hydroxybenzoate })^{-1}$ and $1 \mu \mathrm{mol}$ ( $\mu \mathrm{mol}$ protocatechuate $)^{-1}$. No yellow colour of a putative meta-fission product was seen in the flask during protocatechuate oxidation, and products gave a positive reaction in the Rothera test indicative of ortho-fission of the ring. This was confirmed by preparing the 2,4dinitrophenylhydrazones of products from both protocatechuate and 4-hydroxybenzoate oxidation, and examining them by TLC with solvents A and B. The product from both substrates corresponded to the derivative produced from 3-oxoadipate by the same procedure, as expected for ortho-fission of protocatechuate (Ornston \& Stanier, 1966).

The 4-hydroxybenzoate hydroxylase and protocatechuate oxygenase were induced to high activities by growth on 4-hydroxyacetophenone when compared with the activities in succinategrown bacteria (Table 1), a further indication that they are involved in the metabolic pathway.

\section{Conclusions}

The results are consistent with the pathway shown in Fig. 3 for the catabolism of 4hydroxyacetophenone by Alcaligenes strain PFA, with hydroxylation of the methyl group as the 


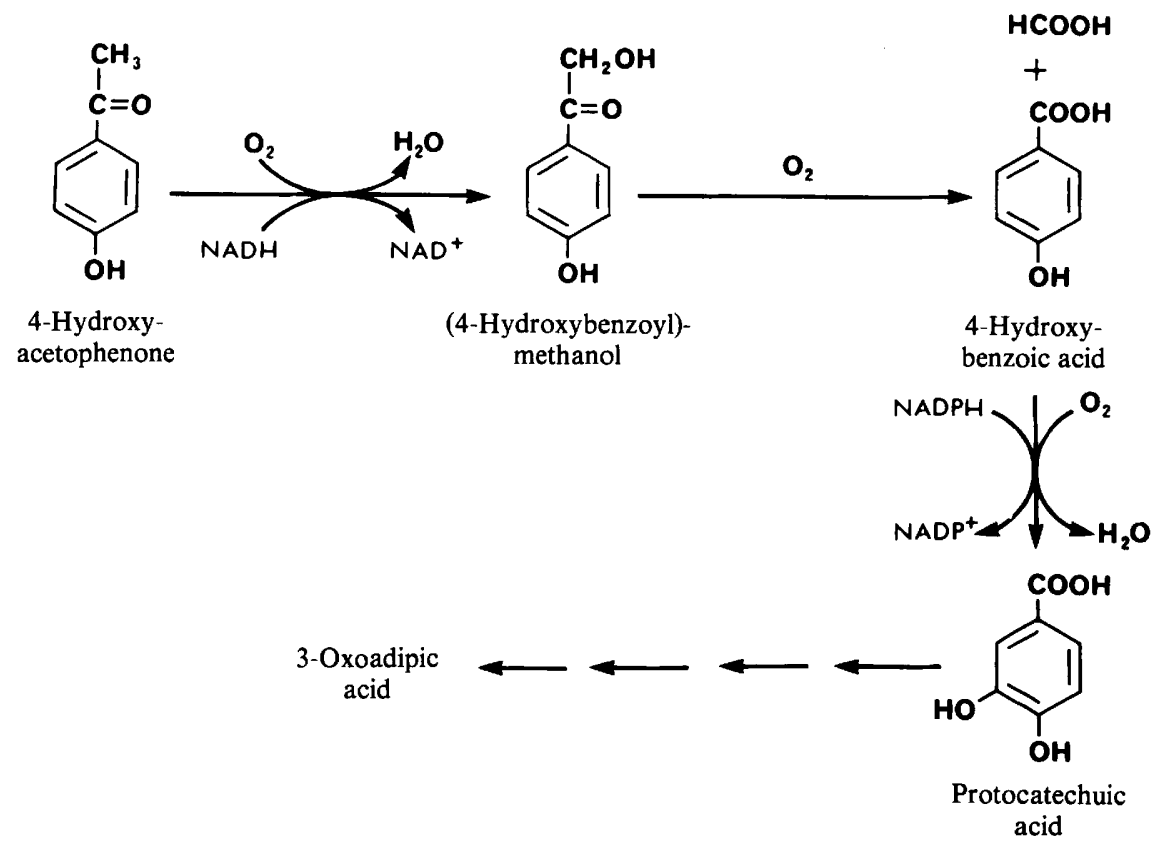

Fig. 3. Proposed pathway for the catabolism of 4-hydroxyacetophenone by Alcaligenes strain PFA.

initial reaction followed by the cleavage of (4-hydroxybenzoyl)methanol. The product, 4hydroxybenzoate, is then metabolized by the well-established route of hydroxylation to protocatechuate and through the ortho-fission pathway to 3-oxoadipate (Ornston \& Stanier, 1966). Thus the reactions by which this organism deals with the ketonic side-chain are very different from the metabolic precedents listed in the Introduction.

Of particular interest is the novel oxidative attack on the bond between carbons bearing oxo and hydroxy groups in (4-hydroxybenzoyl)methanol. Cleavage between such groups has been reported previously for the formation of tartaric acid from 4-oxogluconic acid (Kotera et al., 1972) but this is a two-step reaction analogous to the cleavage of acetophenone with intermediate formation of an ester. Perhaps a closer comparison can be made with the splitting of ribulose 1,5-bisphosphate to glycerate 3-phosphate and glycollate 2-phosphate by the oxygenase activity of ribulose 1,5-bisphosphate carboxylase (Lorimer, 1981), although a study of the reaction using ${ }^{18} \mathrm{O}_{2}$ will be necessary before the enzyme can be defined unambiguously as an oxygenase.

Although this is the first example of this mechanism for cleaving ketonic side-chains it is possibly of wider occurrence. Intermediates of similar structure to (4-hydroxybenzoyl)methanol have been reported in the degradation of lignin model compounds by fungi (Glenn et al., 1983), and in the bacterial degradation of (-)-ephedrine (Klamann \& Lingens, 1980). In the latter case, the cleavage of $\alpha$-hydroxypropiophenone to benzaldehyde and acetaldehyde was tentatively proposed as a possible step in the pathway but without firm supporting evidence, and the identification of benzoic acid as an intermediate suggests that a reaction similar to that described here may occur.

\section{REFERENCES}

CRIPPS, R. E. (1975). The microbial metabolism of acetophenone and some chloroacetophenones by an Arthrobacter species. Biochemical Journal 152, 233241 .

Cripps, R. E., Trudgill, P. W. \& Whateley, J. G.
(1978). The metabolism of 1-phenylethanol and acetophenone by Nocardia T5 and an Arthrobacter species. European Journal of Biochemistry 86, 175186.

Forney, F. W. \& Markovetz, A. J. (1969). An 
enzyme system for aliphatic methyl ketone oxidation. Biochemical and Biophysical Research Communications 37, 31-38.

Glenn, J. K., Morgan, M. A., Mayfield, M. B., Kuwahara, M. \& Gold, M. H. (1983). An extracellular $\mathrm{H}_{2} \mathrm{O}_{2}$-requiring enzyme preparation involved in lignin biodegradation by the white rot basidiomycete Phanerochaete chrysosporium. Biochemical and Biophysical Research Communications 114, 1077-1083.

GUNTER, S. E. (1953). The enzymatic oxidation of $p$ hydroxymandelic acid to $p$-hydroxybenzoic acid. Journal of Bacteriology 66, 341-346.

Holding, A. J. \& Shewan, J. M. (1974). The genus Alcaligenes. In Bergey's Manual of Determinative Bacteriology, 8th edn, pp. 273-275. Edited by R. E. Buchanan \& N. E. Gibbons. Baltimore: Williams \& Wilkins.

HopPer, D. J. \& Elmorsi, E. A. (1984). Cleavage of formate from $\omega, 4$-dihydroxyacetophenone. An unusual oxygen-requiring reaction in the bacterial catabolism of 4-hydroxycetophenone. Biochemical Journal 218, 269-272.

KenNedy, S. I. T. \& Fewson, C. A. (1968). Enzymes of the mandelate pathway in bacterium NCIB 8250 . Biochemical Journal 107, 497-506.

Rlamann, E. \& Lingens, F. (1980). Degradation of (-)-ephedrine by Pseudomonas putida. Detection of (-)-ephedrine: NAD+-oxidoreductase from Arthrobacter globiformis. Zeitschrift für Naturforschung 35c, 80-87.

Kotera, U., Kuulima, T., Minoda, Y. \& Yamada, K. (1972). Isolation and chemical structure of new oxidation product of 5-ketogluconic acid and a hypothetical pathway from glucose to tartaric acid through this new compound. Agricultural and Biological Chemistry 36, 1315-1325.

LORIMER, G. H. (1981). The carboxylation and oxygenation of ribulose 1,5-bisphosphate: the primary events in photosynthesis and photorespiration. $A n-$ nual Review of Plant Physiology 32, 349-383.
Mcintire, W., Hopper, D. J., Craig, J. C., EverhaRT, E. T., Webster, R. V., Causer, M. J. \& SINGER, T. P. (1984). Stereochemistry of 1-(4'hydroxyphenyl)ethanol produced by hydroxylation of 4-ethylphenol by $p$-cresol methylhydroxylase. Biochemical Journal 224, 617-621.

Minamikawa, T., Jayasankar, N. P., Bohn, B. A., TAYLOR, I. E. P. \& Towers, G. H. N. (1970). An inducible hydrolase from Aspergillus niger, acting on carbon-carbon bonds, for phlorrhizin and other C. acylated phenols. Biochemical Journal 116, 889897.

Norris, D. B. \& Trudgill, P. W. (1971). The metabolism of cyclohexanol by Nocardia globerula CLI. Biochemical Journal 121, 363-370.

ORnston, L. N. \& Stanier, R. Y. (1966). The conversion of catechol and protocatechuate to $\beta$. ketoadipate by Pseudomonas putida. Journal of Biological Chemistry 131, 42-48.

RAHIM, M. A. \& SiH, C. J. (1966). Mechanisms of steroid oxidation by microorganisms. XI. Enzymatic cleavage of the pregnane side chain. Journal o, Biological Chemistry 241, 3615-3623.

Robertson, A. \& Robinson, R. (1928). Experiment: on the synthesis of anthrocyanins. Journal of the Chemical Society, 1460-1472.

RonkaINen, P. (1963). Die Dunnschichtchromato graphie der Ketosauren. Journal of Chromatograph. 11, 228-237.

Rosenberger, R. F. \& ElsDen, S. R. (1960). The yield of Streptococcus faecalis grown in continuous culture Journal of General Microbiology 22, 726-739.

RotherA, A. C. H. (1908). Note on the sodiun nitroprusside reaction for acetone. Journal of Physio $\log y$ 37, 491-494.

WHATELEY, J. G. (1978). The microbial metabolism of 1 phenylethanol and acetophenone. $\mathrm{PhD}$ thesis, Univer sity College of Wales, Aberystwyth.

Vogel, A. I. (1956). Practical Organic Chemistry, 3r edn. London: Longman, Green. 